\title{
MEMORYSCAPES: SOUTHEAST EUROPE AND THE QUESTION OF "SMALL/MINOR" LITERATURE
}

GORICA MAJSTOROVIC

STOCKTON UNIVERSITY

\begin{abstract}
Drawing on recent discussions in world literature and Michael Rothberg's concept of multidirectional memory, in the present article I explore Danilo Kiš and Dubravka Ugrešić within the formation of transactional exchanges between "small/minor" and world literatures. As I approach these exchanges, my focus is on texts and contexts in which translation and memory function as the key mediator. By reading Kiš and Ugrešić comparatively, my aim, in what I call "the minor drive," is to address writers and translators that contest hegemonic narratives, and in doing so, examine the cultural enterprise of "small/minor" literatures from the perspective of "worlding" former Yugoslavia and Southeast Europe.
\end{abstract}

Keywords: Danilo Kiš; Dubravka Ugrešić; translation; memory; minor literatures; former Yugoslavia DOI: $10.14712 / 23363231.2021 .3$

\section{Introduction}

Erich Auerbach wrote in Istanbul, a city that had become for him a temporary home after fleeing Nazi Germany in the 1930s, that exile allowed Dante "to correct and overcome that disharmony of fate, not by stoic asceticism and

Dr. Gorica Majstorovic is a Professor of Spanish and World Literature, Stockton University, USA. Address correspondence to 101 Vera King Farris Dr., Galloway, NJ 08205. E-mail: Gorica.Majstorovic @stockton.edu. 
renunciation, but by taking account of memory and historical events." ${ }^{1}$ Michael Rothberg's understanding of memory, through a multidirectional lens, engages the Holocaust and postcolonial histories of violence. Rothberg's concept, I argue in this essay, largely informs memory processes in twentieth-century literatures of Southeast Europe, and more specifically, the former Yugoslavia. The multidirectional memory provides a conceptual framework that allows for an understanding of violence in multidirectional terms, without reducing it to a neutralized suffering, or to historical events seen as disconnected. Rothberg maps out different contexts of multidirectionality and examines the complex set of connections and interactions between such historical contexts as Nazi Germany, slavery, colonialism, and decolonization. In doing so, he argues that the Holocaust is intrinsically connected to other types of traumatic memories. Memory should therefore not be viewed as a competitive "zero-sum struggle" for visibility and recognition, ${ }^{2}$ but rather as a "dynamic process in which disparate and opposing memories exist alongside each other and are often linked."3

While the inequalities ensuing from histories of colonialism persist to the present, taking a cue from translation theory and memory studies, I am interested in alternatives and challenges that multilingualism and translation can provide to national literatures in postcolonial spaces. In doing so, I am primarily looking at exile and statelessness - through the lens of memory and translation - in two authors from small/minor literatures of Southeast Europe: Danilo Kiš (Yugoslavia/Serbia-France) and Dubravka Ugrešić (Yugoslavia/Croatia-Netherlands). While echoing a transnational/transcultural turn in memory studies, I follow Rothberg's problematization of the automatic association between memory and identity. He sustains: "Memories are not owned by groups - nor are groups 'owned' by memories. Rather, the borders of memory and identity are jagged; what looks at first like my own property often turns out to be a borrowing or adaptation from a history that initially might seem foreign or distant." ${ }^{4}$ In other words, public, collective memory works in a cross-referencing way, and the history of the memory can only be written comparatively. While maintaining the comparative focus as I think about memory and translation in this essay, I am

1 Erich Auerbach, Dante, Poet of the Secular World, trans. Ralph Manheim (New York: Riverview Books, 2001), xii.

2 Michael Rothberg, Multidirectional Memory: Remembering the Holocaust in the Age of Decolonization (Stanford: Stanford University Press, 2009), 9.

3 Ibid., 2-3.

4 Ibid., 5 . 
departing from the concept of "translation as consecration" (Pascale Casanova) and focusing on the "materiality" of translation, a literary practice that I read as contesting hegemonic, national narratives.

I examine memory and uses of translation, first in Danilo Kiš (in the 1970s and 1980s), and then in Dubravka Ugrešić (from the 1990s onward). I look at some of the ways in which both authors question in their work assumptions about originality, influence, and literary scale. These concepts are largely inherited from the interwar modernism that both Kiš and Ugrešić follow closely, either through academic study (Kiš was the first graduate of the Department of Comparative Literature at the University of Belgrade, while Ugrešić is a former professor of Slavic and Comparative Literature at the University of Zagreb's Institute for the Theory of Literature), or in their own fiction, their work in translation, and their work as translators. I focus on overlapping cultural transactions within the economies of the "minor" that produce marginal, extracanonical circuits of readership and literary exchange, to and from Southeast Europe.

Rather than examining translation and minority discourse within a single nation-state or stand-alone example of minor languages and cultures in Southeast Europe and former Yugoslavia in particular, I follow the approach exposed in Contextualizing World Literature that proposes the "construction of interlocking and/or reciprocally illuminating multilingual literary clusters. These ensembles are of very diverse shapes: the world, a region, a country, a language block, a network of cross-cultural 'interferences' while the so-called minor literatures invite to question the use of these ensembles." 6 This last point is especially important for my analysis: by questioning the uses of these ensembles, I am taking "small/minor" literature as a relational rather than ontological category. In doing so, I depart from the concept of translation as an organizing, constitutive concept, first for global modernism (Gayle Rogers) ${ }^{7}$ and then for writers who live and work in the cultural fields (Pierre Bourdieu) $)^{8}$ traversed by those particular modernist cultural legacies.

5 Pascale Casanova, The World Republic of Letters, trans. Malcolm DeBevoise (Cambridge: Harvard University Press, 2004), 135.

6 Jean Bessière and Gerald Gillespie, eds., Contextualizing World Literature (Brussels: Peter Lang, 2015), 3. This volume was published following the symposium on world literature held at the International Comparative Literature Association 2013 Paris Congress.

7 Gayle Rogers, "Translation," in A New Vocabulary for Global Modernism, eds. Eric Hayot and Rebecca L. Walkowitz (New York: Columbia University Press, 2016).

8 Pierre Bourdieu, The Field of Cultural Production (New York: Columbia University Press, 1993). 


\section{World Scale and Small/Minor Literatures}

In "Territorial Trap: Danilo Kiš, Cultural Geography, and Geopolitical Imagination," Zoran Milutinović points to cultural mediation and the role of cultural institutions in tastemaking, cultural gatekeeping, and global promotion of literary works from smaller countries. ${ }^{9}$ He contends that most attempts to integrate writers from "small/minor" literatures into a larger whole "tend to be inadequate, deductive, and reductionist." 10 Intrigued by this premise, I am interested in the ways in which the worlding of "small/minor" literatures (the transfer and production of such new meaning through translation, global publishing markets, and emerging cultures of reading) simultaneously reaffirms and also questions the historical memory deposited in Western European archives of the large nation states such as Germany, the UK, and France. By looking at these complex issues, several questions arise: What is the role of the nation-state and its cultural and academic institutions in minor-major literary relations? How might mutual investigation of "small/minor" and "world" literatures complicate understandings of each category's chronologies and cartographies? What is the role of translation as the mediator between the two? What kind of challenge to world literature, if any, can be associated with "small/minor" literatures? How might "the global turn" in comparative literary studies be explored by addressing constructions of "minor Europe," the figure and the practice of translation, and responses to memory and its legacies?

Following Rothberg's views on multidirectionality of memory as an important form of connection and interaction of different historical memories, I seek to explore these concepts of literary study within the formation of transactional exchanges between "small/minor" and world literatures when translation and memory function as the key mediator. In addressing these questions, however, I am not interested in focusing on the many different kinds of minority voices emanating from Southeast Europe. Rather, my aim is to examine the cultural enterprise of "small/minor" literatures from the perspective of "worlding" Southeast Europe. That is to say, I am looking at an interconnected web of cultural networks with "Central Europe" and other geopolitical categories, such as "Western Europe" and "Eastern Europe," at its core.

\footnotetext{
${ }^{9}$ Zoran Milutinović, “Territorial Trap: Danilo Kiš, Cultural Geography, and Geopolitical Imagination," East European Politics and Societies 28, No. 4 (2014): 715-738, doi: $10.1177 / 0888325414543082$.

10 Ibid., 715.
} 
While questioning the boundaries of Anglophone modernism, Gayle Rogers asserts that "one of the central tenets of the modernist reconceptualization of translation is that even foundational notions such as target and source are complicated by a number of factors, geopolitics among them."11 I would go a step further and argue that geopolitics and internal national (cultural) politics are key concepts in translational exchange, but especially so in the complex translation dynamics that involve what Rogers calls "nondominant languages" and "minor-language" texts. For those minor categories to exist there has to be a dominant language and a major-language text, as modernism indeed had at its core the literatures of the Paris-London-New York-Berlin nexus. The centrality of those major literatures and geolinguistic spaces (i.e., languages) in the formation of not only literary scholarship but also memory studies came to the fore, yet again, in the recent centennial commemorations of the First World War.

While a further discussion of this complex topic goes beyond the scope of this essay, the discrepancies between texts written in the "major" languages (English and German, for example) and those coming from the "small/minor" languages and literatures (Serbian and Macedonian, for example) are notable. Aleksandra Mančić, too, has effectively argued that "small" literatures are of interest to large ones only in times of conflict. ${ }^{12}$ In the realm of comparative literary topographies, the process is always a deeply political one that complicates the relationship between large/centric and small/peripheral. Most importantly, it evolves within processes of global modernity, one that is always world-historical and inseparable from political considerations of memory.

\section{Poetics of Memory in Danilo Kiš}

Danilo Kiš (1935-1989) foregrounds in his work the condition of statelessness, the effects of the Holocaust and Stalinism on individuals and states, and the role of memory. Kiš was born in multiethnic Vojvodina, in the border city of Subotica, to a Jewish-Hungarian father and an Orthodox-Montenegrin mother. His father and several other family members died in concentration camps. $B a \check{s}$ ta, pepeo (1965; translated as Garden, Ashes) is Kiš' fictionalized biography and a tribute to his father. Kiš other acclaimed works include titles such as Psalm

11 Rogers, "Translation," 259.

12 Aleksandra Mančić, "Una aproximación traductológica al problema de la cultura del extranjero" (Doctoral Dissertation, Universidad Autónoma Madrid, 2003), 56. 
44 (1962; Psalm 44), Grobnica za Borisa Davidoviča (1976; Tomb for Boris Davidovich), Rani jadi: za decu i osetljive (1970; Early Sorrows: For Children and Sensitive Readers), Peščanik (1972; Hourglass), Enciklopedija Mrtvih (1983; The Encyclopedia of the Dead), and Lauta i ožiljci (1994; The Lute and the Scars), which includes the short story "Apatrid."

Kiš wrote "Apatrid" using a memory genre, a biography. This short story consists of a series of twenty-six brief fragments about the life and work of a literary character whose life closely resembles that of the real-world writer Ödön von Horváth (1901-1938). Von Horváth was a modernist writer and playwright whose work has enjoyed a contemporary revival through translations and reprints, but also theatrical adaptations of his plays, most notably by the late director Igor Vuk Torbica (1987-2020). From 2016 to 2018, Torbica put on stage von Horváth's Tales from the Vienna Woods to great acclaim at the Gavella Theatre in Zagreb, Croatia. The production company traveled across the region and performed in light of worrying political parallels Torbica wanted to show between the rise of fascism in Austria (that von Horváth depicted in the 1930s), and the rising right-wing populisms that currently threaten democracy in the regions of Southeast Europe.

Ödön von Horváth was born in multilingual Rijeka, then Fiume, a city that throughout its history has been marked by constantly changing borders and is now located in Croatia. At the time of von Horváth's birth in 1901, the city belonged to the Austro-Hungarian Empire, bordering Italy. The author's father was a journalist who covered shipping news for the Pester Lloyd newspaper and insurance company; his first posting was in Fiume/Rijeka, a port city on the map of "Europa minor." The geography of "Europa minor" that the story subsequently maps includes first Belgrade, Serbia, where the author's family lived from 1902 to 1908, then Budapest, Bratislava, and Munich. I am borrowing the term "Europa minor" from Andreas Kramer, who derived the phrase from the modernist writer Yvan Goll. Goll used the term kleines Europa to describe post-First World War Central and Eastern European nations (emerging from the demise of the Austro-Hungarian Empire) in a letter to Ljubomir Micić, the editor of the avant-garde journal Zenit, then based in Zagreb. ${ }^{13}$ Kramer studies Goll's use of the trope "Europa minor" to destabilize the European chronotope and its self-appointed centrality and universalism. According to Kramer,

${ }^{13}$ Quoted in Andreas Kramer, “Europa minor. Yvan and Claire Goll's Europe," in Europa! Europa? The Avant-Garde, Modernism and the Fate of a Continent, ed. Sascha Bru et al. (Berlin: De Gruyter, 2009), 131. The Golls (Ivan and Claire) were themselves, like Kišs, and Ugrešić many years later, living in exile away from their "home culture." 
"Europa minor" is in Goll "a spatial and temporal network where avant-garde traffic can flow in various directions at once." 14

The map in "Apatrid" uses real topographies; however, the personal names are changed: Hungarian-Croatian-sounding von Horváth became Hungarian-German-border-located von Németh. As a student in Munich, von Németh became interested in translation:

With the help of a poet he discovered at an early age the mysterious, encrypted language of love. As an eighteen-year-old, in love with a fellow student, a German girl, he discovered that in this poet's work there was one poem for every phase of amour (for raptures, disappointment, dread, regret); and he commenced translating. And so he translated - "completely à propos" - fifty of the poems, and at the point when the love cycle had quickened in the German language and was already in the printer's hands, love evolved for him, via the process of crystallization (to put it in Stendhal-ease), to that point in which passion begins to smolder and go out. All that remained of the whole youthful adventure and amorous delirium was this anthology of translated poems, like some dog-eared photo album. ${ }^{15}$

Bilingual since birth, speaking both Hungarian and German, von Németh translated a collection by the Hungarian poet and celebrated modernist Endre Ady. At this particular juncture and through the act of translation, von Németh opted for the German language: "it's the nearest to my heart. I am, good sirs, a German writer; the world is my homeland." 16

German is also the language of Kafka's Prague and one of the multiple languages of the province of Vojvodina where Danilo Kiš grew up. Indeed, Kiš is deeply imbedded within the multidirectional memory, multicultural identification, and multilingualism of the region. As a child, he briefly lived in Novi Sad where he continued to learn Hungarian, knowledge that later enabled him to translate Ady from Hungarian to Serbo-Croatian. In "Apatrid," Kiš puts von Németh's identity in the following terms: "I am a typical mixture from the Habsburg Empire of blessed memory: simultaneously Hungarian, Croat, Slovak, German, Czech ... [with] traces of Tsintsar, Armenian, and yes, maybe even

14 Kramer, "Europa minor," 136.

15 Danilo Kiš, "The Stateless One," in The Lute and the Scars, trans. John K. Cox (Champaign: Dalkey Archive Press, 2012), 10.

${ }^{16}$ Ibid., 12. In the first chapter of Ödön von Horváth’s first novel, The Eternal Philistine (1930), titled "Herr Kobler becomes a Pan-European," the protagonist goes from Germany to the 1929 Barcelona Universal Exposition. 
Roma and Jewish blood." 17 As a key quality of what they called "a minor literature” Deleuze and Guattari emphasize the significance of Kafka's experience of multiple cultural identities as a German-speaking Jew from (the then Austro-Hungarian) Prague. Minor literatures, they argue, have a "high coefficient of deterritorialisation" of language; "everything in them is political, and the assemblage of enunciation is collective." 18 Indeed, Kiš" cosmopolitan protagonist, "the man without the country, the stateless one," 19 is assembled through these collective histories and their overlapping geopolitical and geolinguistic marks of multidirectional memory.

In the story (and in real life), von Németh (von Horváth) subsequently travels through Italy, Yugoslavia, and Hungary before arriving in Amsterdam. It is in Amsterdam where he meets his publisher Mr. van der Lange and prepares his new novel, Farewell to Europe. An important stop he makes on this journey is a visit to Pest, the heart of (his familiar space of Austro-Hungarian) Europe and where his father lives. The Austro-Hungarian Empire, dismantled since the end of the First World War in 1918, lives on in the cultural memory of Kiš and his protagonist, a fellow writer. Kiš, however, is unmistakably a writer from a small country in Southeast Europe, to the south of Pest. Budapest (and Vienna, with its German language) is where high culture resided at the time. It is a place with undisputed "major" cultural capital. The publisher that von Németh meets in Amsterdam also loves German literature: "Heine was the first writer to poison him with poetic reveries and teach him the difference between the lyrical and the ironic, as well as the fragile relationship between them - a knack that is hard to find among poets as it is among readers." ${ }^{20}$ Upon summing up the tenets of this unique style, always oscillating between the lyrical and the ironic, Kiš goes on to highlight the important work that van der Lange accomplished: in the 1930s he published books by German refugees fleeing fascism. As one such refugee during this time, the real writer, Ödön von Horváth, was forced to leave Germany and, after a brief stay in Amsterdam, went on to Paris.

Amsterdam, for several reasons, gets a much longer description in Kiš' story than Paris. Most importantly, Amsterdam is portrayed as a refuge from fascism, in contrast to Germany where "masses howled in stadiums." ${ }^{21}$ Amsterdam, the

17 Ibid.

18 Gilles Deleuze and Félix Guattari, Kafka: Toward a Minor Literature (Minneapolis and London: University of Minnesota Press, 1986), 17.

${ }^{19}$ Kišs, "The Stateless One," 15.

20 Ibid.

${ }^{21}$ Ibid., 17. 
narrator says, is "another world altogether ... the market women, ... the young men on the bicycles ... boats moved calmly along on the canals ... through narrow uncurtained windows families could be seen around tables with steaming dishes of food: bright accents on idyllic scenes of family life, the way they would have appeared on the canvas of a Dutch master." 22 At the end of the story, an Amsterdam fortune-teller sends the writer on a journey to Paris, where, as if answering a death call, he goes without hesitation. One day, a storm strikes the city and a falling branch kills von Németh instantaneously. 23

My analysis of Kiš story brings together and confronts "center" perspectives on the world deriving from Paris with "peripheral" ones that are issued from the margins of Europe, dislocating both in the process. I would like to suggest that Kiš displays the "minor drive" though a specific lens of the "world" created by the "small/minor" literatures inflected by the Heinean principle of lyricism and irony. Sought in a series of dialectical tensions that more often than not took the form "Paris and the others," in Kišs story those tensions are underlined with not a small amount of irony and distance. This irony is the most poignant when he addresses nationalism, as he does in regard to his protagonist's legacy:

Back in his homeland this poet had a monument, and streets, named after him; he had generations of admirers and his own mythos, as well as followers who praised him to the skies and stood in awe of his verse and lyrics as the pure emanation of the national spirit; and he also had sworn enemies who considered him a traitor to national ideals. ${ }^{24}$

One cannot help but read Kiš' own life story inserted between the lines of "Apatrid," for it had not been long ago that he chose exile over literature written in a "national" key. In fact, Kiš wrote in the "minor key" (by rejecting the grandiosity of "major," national myths), and he returned the most prestigious literary award (NIN-ova nagrada), finally leaving Belgrade (and certain circles of Serbian cultural nationalism) for France. In sum, while he cannot be easily typecast as a "dissident" in exile, Kiš nevertheless left Belgrade (after a public scandal involving resentment of Kiš' cosmopolitanism by the local nationalist literary clique). He went on to teach Serbo-Croatian at the Universities of Strasbourg, Bordeaux, and Lille before permanently settling in Paris in 1979.

\footnotetext{
22 Ibid.

23 This is exactly how Ödön von Horváth died in 1938, in front of the Marigny Theatre on Avenue des Champs-Élysées.

${ }^{24}$ Kiš, "The Stateless One," 7.
} 
In the next section, let us turn to Kiš own translations, their long-lasting impact and their relevance today. Mostly known as a short story writer whose own prose has been widely translated around the world, Kiš' life-long work as a translator has not yet been examined in the world literature contexts, except for the recent study by Sibelan Forrester. ${ }^{25}$ He translated works into Serbo-Croatian, a language whose hyphen has been violently erased by nationalist discourse, thus converting it into "either" one "or" the other South Slavic language. In contrast to the discourses of nationalism and nationalist literatures that stirred the civil war in the Balkans, I would like to suggest that Kiš used world literature and translation as a cosmopolitan tool, an instrument through which he further resisted nationalism.

Kiš took account of historical events by writing creative fiction and by memorializing the victims of the Holocaust. In doing so, he also denounced the horrors of Stalinism and, I would argue, made particular choices as a translator. Kiš translated French poetry by Corneille, Baudelaire, Lautréamont, Verlaine, Prévert, and Queneau (including Queneau's Exercises in Style, a collection of 99 retellings of the same story). While most of his translations were from French, he also translated Mandelstam, Yesenin, and Tsvetaeva from Russian, and Ady, Petőfi, and Radnóti from Hungarian.

Kiš often said in interviews that he enjoyed translating poetry the most. He translated numerous poems by Marina Tsvetaeva, for example, that were published in a separate edition and also in several anthologies. According to Forrester, "He may have been drawn to Tsvetaeva's poetry not only for its quality, but especially for its treatment of loss, exile, and separation." 26

Susan Sontag, Iosip Brodsky, Salman Rushdie, and Milan Kundera were all vocal fans of Danilo Kiš, and he was invited twice to the meetings of the American PEN. After being "consecrated" in Paris, his work appeared in The New Yorker in the 1980s and his novel A Tomb for Boris Davidovich appeared in Penguin's Writers from the Other Europe, curated by Philip Roth. However, despite all the previous fame, when Mark Thompson started writing his 2013 biography of Kiš, Kiš’ work was all but out-of-print in English. ${ }^{27}$ Thankfully, Dalkey Archive Press, led by late John O’Brien, has since re-translated five novels and several

25 Sibelan Forrester, "The water of life: Resuscitating Russian avant-garde authors in Croatian and Serbian translations," in Contexts, Subtexts and Pretexts: Literary translation in Eastern Europe and Russia, ed. Brian James Baer (Amsterdam: John Benjamins Publishing Company, 2011).

${ }^{26}$ Ibid., 123.

${ }^{27}$ For a brilliant critique of this biography and for the larger implications for the theory of "small/ minor" literatures, see Zoran Milutinović's “Territorial Trap." 
short story collections, among them Kiš’ poignant anti-totalitarian collections of short stories, A Tomb for Boris Davidovich and The Lute and the Scars.

Pascale Casanova claims that "the international recognition of Danilo Kiš coincided with his consecration via translation into French, which lifted him out the shadow of his native Serbo-Croatian." ${ }^{8}$ In Casanova's estimation, Kiš is woefully undervalued. He belongs, she claims, at the center of European literature, not on its fringes. It is interesting to note here Casanova's cosmopolitan "tastemaking" gesture but also her differentiation between large/major centers such as France and Paris and the small/minor ones of Kiš' literary topography. She tries to bring Kiš from the fringes of Europe, from a small language such as Serbo-Croatian, to the center of the "world republic of letters," Paris. As I have indicated earlier, I am interested in the concept of "translation as consecration" (as in Casanova), but also in the idea of translation as a form and practice of ideological resistance that, following Kiš, points to the craft of writing and "the relativity of all myths," especially those belonging to nationalism and nation-building.

\section{Confiscation of Memory in Dubravka Ugrešić}

The first English PEN Writers in Translation Award was given in 2005 to the Croatian writer Dubravka Ugrešić for her novel titled Ministarstvo Boli (2004; translated as The Ministry of Pain). Ugrešić is the award-winning author of essays such as Kultura laži (1996; The Culture of Lies), Europa u sepiji (2013; Europe in Sepia), and Doba kože (2019; The Age of Skin), short story collections such as Štefica Cvek u raljama života (1981; In the Jaws of Life), and novels including Muzej bezuvjetne predaje (1998; The Museum of Unconditional Surrender) and Lisica (2017; Fox). Thirty years since the outbreak of the civil war that brought the dissolution of Yugoslavia and propelled her exile, Ugrešić still lives in Amsterdam and continues to oppose Croatian nationalism (whose proponents once labeled her a dangerous "witch"). ${ }^{29}$ Ugrešić and the characters in her books formulate their own post-Yugoslav memories in multidirectional ways by connecting to people from various countries and backgrounds, and also by drawing on the institutional memories of the Holocaust in Germany (The Museum of

28 Casanova, The World Republic of Letters, 135.

29 "Nationalism is first and foremost individual and collective paranoia, as Danilo Kiš wrote." See “Dubravka Ugrešić by Svetlana Boym,” Bomb Magazine, July 1, 2002, https://bombmagazine.org/ articles/dubravka-ugre\%C5\%A1i\%C4\%87/. 
Unconditional Surrender), the Soviet literary past in the USSR (Fox), and popular culture in Yugoslavia (In the Jaws of Life).

The Ministry of Pain begins with a translation of a 1934 poem by Marina Tsvetaeva: "Those pangs of homesickness!/ That long since detected upheaval!/ I am altogether indifferent/ As to where to be altogether ... Nor am I charmed by my mother/ Tongue's call, cajoling and creamy:/ I set no great store by the tongue that others/ use to misconstruct me ... And closest of all, perhaps, is the past." 30 The past, or more specifically the Yugoslav past, is what haunts the main character's memory in The Ministry of Pain. In this novel, Ugrešić follows a Croatian academic's flight to the Netherlands from the ruins of Yugoslavia in the early 1990s.

Like the author, the professor/protagonist of Ugrešićs novel, Tanja Lucić, is displaced from the Balkan wars of the 1990s and living in Amsterdam. Her partner, Goran, was recently fired from the University of Zagreb:

He was a fine mathematician and much loved by his students, and even though his was in a "neutral" field he'd been removed from his post overnight. Much as people assured him that it was all perfectly "normal" - in times of war your average human specimen always acted like that, the same thing had happened to many people, it happened not only to Serbs in Croatia but to Croats in Serbia, it happened to Muslims, Croats, and Serbs in Bosnia; it happened to Jews, Albanians, and Roma; it happened to everybody everywhere in that unfortunate former country of ours. ${ }^{31}$

Goran ends up taking a position at the University of Tokyo while Tanja starts teaching Yugoslav literature in Amsterdam.

While recalling Tanja's and her students' mistrust of identity and the newly-established languages of Bosnia, Croatia, and Serbia, the novel is composed on the premise of multidirectional memory. Indeed, Tanja's students come from all spaces of former Yugoslavia. It is no secret, and no small irony, that they take the course on Yugoslav literature only because taking it will help them maintain legal status in the country. The work that Tanja is requesting from her students is based on memory. She asks them to recollect moments from their past lives and write essays about them, thus delving into her own trauma and loss. The students

\footnotetext{
${ }^{30}$ Dubravka Ugrešić, The Ministry of Pain, trans. Michael Henry Heim (New York: Harper Collins, 2009), 11.

${ }^{31}$ Ibid., 18.
} 
mostly write about their childhood, seen as an idyllic time prior to "the breakup of the country, the war, the repression of memory ..., and then the exile."32

Memory plays a key role in all of the student narratives and throughout the book:

stimulating the memory was as much a manipulation of the past as banning it. The authorities in our former country had pressed the delete button, I the restore button; they were erasing the Yugoslav past, blaming Yugoslavia for every misfortune, including the war. ${ }^{33}$

Tanja's own endless train journeys are born of a fear, David Williams notes,

of a need to establish semantic and external coordinates, to locate fixed points of reference. This fear of disappearing is shared by her fellow Yugoslav exiles in Amsterdam, who, grieving for lost environments and places of memory, desperately search for surrogates in their new surroundings - for their benches on the waterfront, their town squares, their local cafés. ${ }^{34}$

However, Tanja not only questions identity but also nostalgia and her reliability as a narrator, wondering if she is using Amsterdam as a projection screen for her own memory and the collective Yugoslav trauma.

She chooses to probe her students with memories of the old country through an examination of "Yugo-nostalgia," a term that I find somewhat similar to the Gallician-Portuguese saudade. This term appears as one of the "untranslatability" entries in the translation from French of the Dictionary of Untranslatables. ${ }^{35} \mathrm{In}$ fact, Emily Apter has advocated for "translating untranslatability" and although she uses an entirely different set of examples, she nevertheless argues not against but for translation, albeit one that seeks to embrace infidelity to the original. The narrator in The Ministry of Pain sums this dynamic up in the following terms: "As for the whole, it was untranslatable: we were speaking an extinct language comprehensible only to ourselves." 36 Somewhat similar to saudade, Yugo-nostalgia is

32 Ibid., 52.

33 Ibid., 72.

${ }^{34}$ David Williams, Writing Postcommunism: Towards a Literature of the East European Ruins (London and New York: Palgrave, 2013), 103.

35 "How to Use This Work," in Dictionary of Untranslatables: A Philosophical Lexicon, ed. Barbara Cassin, Emily Apter, Jacques Lezra, and Michael Wood (Princeton: Princeton University Press, 2014), xxi.

36 Ugrešić, The Ministry of Pain, 78. 
indeed an "untranslatable term" that at the same time paradoxically calls for the use of memory and translation as it tells the disjointed stories of "traumatic" and multilingual cosmopolitanism.

Like the narrator in Kiš "Apatrid," Ugrešić's novel deconstructs romantic myths of home and state, a tendency that comes to the fore in the fragment of the novel in which Tanja returns to Zagreb, the Croatian city where she grew up. As David Williams succinctly observes, "Tanja's visit home also prompts some of the novel's strongest reflections on historical remembering and forgetting." ${ }^{77}$ The city that she arrives to in order to visit her mother is no longer recognizable, the street names have changed, and the language spoken around her sounds different. While the analysis of the complex and contentious socio-political backdrop to the Balkan wars and post-Yugoslav states goes beyond the scope of this essay, another stroke of irony is added when a fellow Croatian advises Tanja that the sooner she forgets Zagreb's old street names (from the time of Yugoslavia) and learns the new ones (given by the new state of Croatia), the better.

Ugrešić's writing is especially attuned to issues of "place," "memory," and "mediation." Similar to Kiš, she has always used irony and humor as a serious political tool to examine both the past and the present. However, she has avoided facile characterizations of exile and has been actively involved in contextualizing her own condition of exile. In one interview, for example, she commented on the burden of such a position. When asked whether she disagrees with those who try to identify her as an émigré, political exile, or fugitive, Ugrešić responded:

In the places I live/reside in, I do not want this identification. It is reductive and extremely manipulative. Both exiles and the environment in which exiles find themselves manipulate with this identification. Exile is citational - it has had a long tradition and its meaning has petrified, so it happens that an exile is read entirely on the basis of this "exile complex." And I do not want this. On the other hand, when I address my message to the place I had left - to Croatia and Former Yugoslavia then I insist on exile, that is, on political exile. ${ }^{38}$

37 Williams, Writing Postcommunism, 115.

38 Quoted in Vedrana Veličković, "Open Wounds, the Phenomenology of Exile and the Management of Pain: Dubravka Ugrešićs The Ministry of Pain," in Literature of Exile of East and Central Europe, ed. Agnieszka Gutthy (New York: Peter Lang, 2009), 140. Along similar lines, Ugrešić spoke in New York on May 6, 2017, at the PEN World Voices Festival panel which was dedicated to the critique of nationalism. She shared the panel with writers Aleksandar Hemon (Bosnia-USA) and Igor Śtiks (Bosnia-USA-Scotland-Serbia). 
In “The Confiscation of Memory," an essay from Kultura laži (1996; The Culture of Lies), Ugrešić writes about a couple living in Zagreb, Yugoslavia. The narrative proceeds to tell the story of old summer-time friends who are now on the wrong side of the ethnic divide during the war. The couple had come to Croatia from Bosnia, and their apartment resembled a living museum of Yugoslav everyday life, with a picture of President Josip Broz Tito (1892-1980) hanging on the wall among the family photographs, and souvenirs from summer vacations on the Adriatic Sea decorating the bookshelves. Ugrešić focuses on the problem of memory and remembering by choosing to pay attention only to small/ minor detail in her evocation of Yugoslavia and the country's multiethnic past. She purposefully does so in order to counter and contest the hegemonic national narratives that were subsequently re-constructed in the post-Yugoslav societies. Multidirectional memory, in Michael Rothberg's terms, shows how cultural artefacts travel within and across the various borders of spaces, time, and social groups as Ugrešić invites the contemporary reader to think about remembering those histories and events outside of the borders of their national, social, and cultural identity.

In moving to a close, let us take a look now at some translations of Ugrešić's own work. It is interesting to note that she is perhaps read more outside of Croatia than in the country. While Ugrešić herself translated avant-garde writers such as Boris Pilnyak and Daniil Kharms (from Russian into Croatian), translators of her own work continue the task of disseminating anti-nationalist and anti-totalitarian texts and ideas. Ugrešićs novel The Ministry of Pain, for example, was translated by the late Michael Henry Heim. Ellen Elias-Bursać translated Ugrešić's book of essays Nobody's Home, among other works, including those by David Albahari, the Serbian-Jewish author who spent many years in Canada before returning to Belgrade.

David Williams translated Ugrešić's Karaoke Culture and Europe in Sepia, and co-translated (with Ellen Elias-Bursać) Ugrešić's latest novel, Fox. ${ }^{39} \mathrm{He}$ points to stark asymmetries between large/major and small/minor cultural fields (and power differentials at play) in the "task of the translator":

The point is this: just as there is an enormous difference between being a German or Norwegian writer and a Croatian or Slovak one, there is an enormous difference

39 Dubravka Ugrešić, Karaoke Culture, trans. David Williams (Rochester, NY: Open Letter, 2011); Dubravka Ugrešić, Europe in Sepia, trans. David Williams (Rochester, NY: Open Letter, 2014); Dubravka Ugrešić, Fox, trans. David Williams and Ellen Elias-Bursać (Rochester, NY: Open Letter, 2018). 
between being a translator from the German or Norwegian and being a translator from the Croatian or Slovak. The world of literature in translation is like the Olympics. It's pay-to-play, and, as a general rule, who spends most wins. To win, you need a state that finances fellowships and foundations, scholarships and subventions, consulates and cultural centers, not to mention author tours or - manna from heaven "talks with the translator." In short, literature in translation is a state-sponsored art. This is probably a good time to mention that, given her relationship with the state of Croatia, Dubravka Ugrešić is more or less a stateless writer. ${ }^{40}$

This statelessness unites Ugrešić with Kiš, and, as Williams points out, "if Museum was primarily a novel of museums and the technologies of memory, its chronotope dispersed throughout the ruins of the European twentieth century, The Ministry of Pain narrows its focus to post-1989 eastern Europe," 41 and more directly, to the dissolution of Yugoslavia.

\section{Conclusion}

When I think of Kiš and Ugrešić's use of translation as a tool of resistance to nationalism, a novel called An Unnecessary Woman by the Lebanese writer Rabih Alameddine comes to mind. The protagonist of this novel, who lives alone in Beirut, previously ran a bookstore. Once a year, she translates a favorite volume into Arabic: Anna Karenina by Leo Tolstoy, Austerlitz by W. G. Sebald, Hourglass by Danilo Kiš. Her translations, however, sit stored in boxes in her apartment and, according to her wishes, remain unpublished. She translates not for fame or literary consecration but in order to save her soul and survive the Lebanese civil war. However, unlike the translations of Alameddine's protagonist that remain unknown, Kiš' translations and theatre adaptations were rather well-known and performed in Belgrade, especially at the avant-garde Atelje 212.

The historical events around the civil war of the 1990s and the dissolution of Yugoslavia remain intertwined with the complex memory politics of this era, as I examine the influence Danilo Kiš exerted on the theory and practice of translation and on the whole generation of exiled translators in the aftermath of the war. Kiš work was produced in the earlier decades (he died right before the

\footnotetext{
${ }^{40}$ David Williams, "On the Untranslatability of Translation," World Literature Today (blog), January 3, 2017, https://www.worldliteraturetoday.org/blog/translation-tuesday/untranslatability-translation-david-williams.

41 Williams, Writing Postcommunism, 99.
} 
outbreak of the war), but it foreshadows what would come and speaks loud and clear against the Balkan nationalisms and right-wing populisms of today. Indeed, translation has long been a tool of resistance and survival, literally and figuratively, for Kiš and for the generation of intellectuals known as the post-Yugoslav diaspora.

Translation is cultivated with special care in smaller nations where texts from both major and minor languages and their readers intersect, exposing multidirectional memory and what I call a "minor drive." Modern-day Serbia and Croatia continue the strong translation legacy established in the former Yugoslavia as many works continue to be translated and the industry, despite the setbacks and bookstore closures, continues to resist nationalism(s) through translation. Translation offers a glimpse of critical cosmopolitanism, I would argue, of that other utopian world beyond the confines of one's nation. Indeed, Shingo Shimada states that "translation processes genuinely play a fundamental role in the ways all non-European cultures see themselves." 42 I would go even further to suggest that translation plays a fundamental role in the ways all Western and non-Western so-called "minor" cultures see themselves, including those of Southeast Europe. What strikes me in these encounters are ways in which translation and textual circulation contribute to shaping cultural contact and uses of memory.

To sum up, by addressing Kiš and Ugrešić's work I have approached originality, influence, and the question of "small/minor" literature within the cultural production of these overlapping geopolitical and geolinguistic spaces. I argued that although the term kleine or "small/minor" literature implies a sense of hierarchical order, the way in which Kiš and Ugrešić use this category suggests a process of scrutinizing - if not outright breaking - of hierarchies (major/ minor, dominant/non-dominant, large/small, center/periphery, etc.). However, those same breaking points simultaneously indicate (through its fissures) the residues of geopolitical history and its historically-based categories/ensembles: dominant/non-dominant, center/periphery, major/minor, metropolis/colony. While questioning the uses of these ensembles and their geographic and literary terms of reference, Kiš' and Ugrešić's texts ultimately aim at decentering some long-standing notions in world literature.

42 Quoted in Doris Bachmann-Medick, “Introduction: The Translational Turn," Translation Studies 2, No. 1 (2009): 13, doi: 10.1080/14781700802496118. 